\author{
위산 환경에서 피막형 스텐트의 물성 변화 \\ 박성철**\# - 박낙순\# - 김동곤** - 나재운*** - 진윤태 ${ }^{\dagger}$ 조혜진 - 김은선 · 금보라 \\ 서연석·이홍식 · 전훈재 · 엄순호·김창덕 · 류호상 \\ 고려대학교 의과대학 내과학교실, *강원대학교 의학전문대학원 내과학교실, \\ **(재)유타-인하 DDS 및 신의료기술개발 공동연구소, ***순천대학교 고분자공학과 \\ (2013년 11월 30일 접수, 2014년 1월 11일 수정, 2014년 1월 24일 채택)
}

\title{
Physical Properties of Covered Stent in Gastric Acid Environment: In Vitro Study
}

\author{
Sung Chul Park*,, Nark-Soon Park", Dong-Gon Kim**, Jae-Woon Nah***, Yoon Tae Jeen ${ }^{\dagger}$, Hye Jin Cho, \\ Eun Sun Kim, Bora Keum, Yeon Seok Seo, Hong Sik Lee, Hoon Jai Chun, \\ Soon Ho Um, Chang Duck Kim, and Ho Sang Ryu \\ Department of Internal Medicine, Korea University College of Medicine, Seoul 136-705, Korea \\ *Department of Internal Medicine, Kangwon National University School of Medicine, Chuncheon 200-701, Korea \\ **Utah-inha DDS \& Advanced Therapeutics Research Center, Incheon 406-840, Korea \\ ***Department of Polymer Science and Engineering, Sunchon National University, Jeonnam 540-742 Korea
}

(Received November 30, 2013; Revised January 11, 2014; Accepted January 24, 2014)

\begin{abstract}
초록: 위장관 종양 조직이 스텐트 내로 성장하는 것을 방지하는 피막형 스텐트가 개발되어 널리 사용되고 있으나 위 산에 의한 막의 분해로 인해 스텐트 폐쇄나 파손이 있다. 이에 본 연구에서는 위산 환경하에서 막의 성분과 재질 농 도에 따른 피막형 스텐트의 물성 변화와 안정성을 살펴보고자 하였다. 스텐트 막의 재질은 실리콘과 폴리우레탄을 사 용하였고, 각각의 농도를 $15 \%, 18 \%, 20 \%$ 로 하여 제작된 스텐트를 $\mathrm{pH} 1.2$ 산성 용액에서 18 주 동안 3 주 간격으로 변화를 관찰하였다. 피막을 분석한 결과 동일 농도에서 비교하였을 때 실리콘이 폴리우레탄보다 두껍고 균일하게 코팅되었다. 인공 위액에 의한 폴리우레탄 피막의 분해가 실리콘 피막에 비해 심하였다. 반경 방향 팽창력의 크기는 실리콘 피막이 폴리우레탄 피막에 비해 상대적으로 컸다. 반경 방향 팽창력과 변형 회복력 모두 인공 위액에서의 침잠 기간이 경과함에 따라 점차 감소하였고, 폴리우레탄 피막 스텐트에서 감소율이 더 컸다. 결론적으로 실리콘 피 막이 폴리우레탄에 비해 위산에 대해 안정성이 높음을 알 수 있었다.
\end{abstract}

\begin{abstract}
In membrane covered stent, occlusion and fracture from membrane degradation by gastric acid sometimes occurred. Therefore, we investigated the physical properties of membrane covered stent according to its ingredient and concentration in gastric acid environment. Membrane covered stents consisted of silicone and polyurethane with $15 \%$, $18 \%, 20 \%$ concentrations were used. After incubating stents in a condition of $\mathrm{pH} 1.2$, we checked any changes at every 3 weeks for 18 weeks. The changes of membrane surface, radial expansion and recovery force of stent were investigated. Coating thickness increased proportionally to an increase in ingredient concentration. Surface was evenly coated with silicone compared to the case with polyurethane and its homogeneity was excellent in a high concentration. Degradation was much severe in the case of polyurethane. The radial force of silicone was higher than polyurethane, and the decrease of radial and recovery force was higher in the case of polyurethane. In conclusion, high concentration of silicone membrane was more stable than polyurethane in acid environment of in vitro study.
\end{abstract}

Keywords: covered stent, physical property, gastric acid, silicone, polyurethane.

\section{Introduction}

Stenting in the upper gastrointestinal (GI) tract is generally

\footnotetext{
\#Both authors contributed equally to this work.

${ }^{\dagger}$ To whom correspondence should be addressed.

E-mail: ytjeen@korea.ac.kr
}

considered a conservative treatment for strictures associated with malignancies in the stomach, esophagus, biliary tract, and pancreas; this approach is the preferred method when radical surgery is not indicated. ${ }^{1}$

Its application has recently included benign strictures caused by complications of peptic ulcer, reflux esophagitis, the sur- 
gery of the GI tract, and the ingestion of the corrosive drugs. ${ }^{2}$

Plastic stents were initially used in this procedure but were later replaced by self-expandable metal stents (SEMSs) in the late 1980s, after being proven to have a superior clinical efficacy, with its ease in insertion and positioning and low risk of tissue damage during insertion. SEMSs are available in two forms, depending on its covering: membrane covered and membrane uncovered. ${ }^{1}$ Membrane-uncovered stents have the advantage of good adhesion and easy maneuvering, although it also presents the risk of tumor ingrowth within the stent, which may then lead to stent occlusion. Membrane covered stents were developed to address these drawbacks and are replacing uncovered stent. These membrane-covered stents contain a layer of metal alloy wire coated with a thin membrane of silicone or polyurethane. Although these stents preventing tumor ingrowth into the metal alloy wire and is easily removable, there is an increased tendency for stent migration.

The ideal features of an effective membrane-covered stent include excellent biocompatibility and long-term potency, which is largely influenced by its durability against various biochemical and mechanical stressors present in the insertion area. However, most stents, including membrane-covered stents, are associated with fistula recurrence or stent fracture, and these are attributable to the change of physical properties of membrane..$^{3-6}$ Two major factors associated with membrane degradation of the stent have been related to this occurrence: (1) Biochemical damages caused by strongly acidic gastric juice and bile, as well as pancreatic enzymes, and (2) Mechanical damage to the stent due to peristaltic movement of the GI tract or the pressure exerted by the surrounding tissues. ${ }^{7}$

Silicone, polyurethane, and e-PTFE (expanded polytetrafluoroethylene) have been mainly used as stent coating materials and different membrane-covered stents are currently available. To select the optimal stent for long-term functional maintenance of a specific lesion, it is essential to understand the properties of the stents based on its material and production, in relation to the anatomic structure of stricture area. However, a comparative analysis of the advantages and disadvantages of each stent type is limited, and thus, most clinicians base the selection of stents on their individual experiences. ${ }^{8}$

This study examined the coating thickness of the SEMS that were coated with silicone and polyurethane of different material concentrations and observe the changes in physical properties including membrane degradation after immersing it in simulated enzyme-free gastric acid. These in vitro experiments allowed us to monitor changes in the stability and physical characteristics of membrane-covered SEMS in the gastric acid environment in relation to the membrane composition and material concentration.

\section{Experimental}

Materials and Method. Hanaro biliary stents were supplied by M.I.Tech Co. (Seoul, Korea). Polyurethane (Pellethane 2363-80AE) and silicone (MED-6640) were purchased from Dow chemicals (Korea) and Uusil technology (USA), respectively. Tetrahydrofuran (THF) was obtained from Sigma Co. (USA). All reagents used were of extra pure reagent grade without any need for further purification. A $0.14-\mathrm{mm}$ nitinol (nickel and titanium alloy) shape memory alloy wire was woven into a SEMS of $10-\mathrm{mm}$ diameter and $80-\mathrm{mm}$ length and coated with various concentrations $(15,18$, and $20 \%(\mathrm{w} /$ w)) of silicone and polyurethane as the cover material. Polyurethane and silicone membranes were fabricated using the dip coating method. Polyurethane and silicone were dissolved in THF and then vigorously stirred to obtain a hemogenous membrane coating solutions. Dip coated stents were dried at $60{ }^{\circ} \mathrm{C}$ for $24 \mathrm{hr}$. Seven stents of each type were manufactured to yield 42 covered SEMS.

Simulated Gastric Acid Environment. Simulated gastric acid ( $\mathrm{pH}$ 1.2; $\mathrm{pH}$ adjusted using $\mathrm{HCl}$ ) was prepared according to the liquid processing method for dissolution testing described in the Korean Pharmacopoeia, 7th edition. Briefly, 2 $\mathrm{g}$ of $\mathrm{NaCl}$ was dissolved in $7 \mathrm{~mL}$ of concentrated hydrochloric acid; the mixture was then diluted to $1 \mathrm{~L}$ with water. Each type of membrane-covered stent was then immersed in the simulated gastric acid at $37^{\circ} \mathrm{C}$ and $100 \mathrm{rpm}$. The stents were collected at 3-week intervals $(0,3,6,9,12,15$, and 18 weeks) and examined for any structural changes.

Assessment of Changes on the Membrane Surfaces. Sampling of the silicone and polyurethane stents was conducted at 0,9 , and 18 weeks. The membranes were peeled off, cut into $1 \times 1 \mathrm{~cm}$ squares, and subjected to gold coating for analysis by using a scanning electron microscope (SEM, SNC$3000 \mathrm{M}$, SEC Co.) with a total magnification of $2000 \times$.

Assessment of Changes in Physical Properties Caused by Decomposition. Measurement of Radial Expansion Forces: To measure the expansion force exerted on the stricture area from the lumen where the stent is positioned, a pushpull gauge (FGS-50V-H FGC-2, NIDEC-SHIMPO Corp., Japan) was used. At a room temperature of $24{ }^{\circ} \mathrm{C}$, we measured the force by pressing the cylinder head (diameter: $30 \mathrm{~mm}$ ) to the 
point of $1 / 2$ of the stent diameter at the speed of $5 \mathrm{~mm} / \mathrm{min}$.

Measurement of Recovery Force: To measure the force of the stent to recover its original straight shape after it was positioned in the form of a curved body lumen, a universal testing machine (3344 model, Instron Inc., Norwood, MA, USA) was employed. At a room temperature of $24{ }^{\circ} \mathrm{C}$, we measured the recovery force of a stent that was placed on a platform with a span length of $22.5 \mathrm{~mm}$ and deliberately bent at a speed of $5 \mathrm{~mm} / \mathrm{min}$ (3-point bending test).

\section{Results and Discussion}

\section{Comparison of Coating Thickness of Silicone/Polyure-} thane-covered Stent (Table 1). The mean thickness of stents made up of $15 \%$ silicone concentration $(\mathrm{N}=7$ specimens) was measured at $121.9 \pm 1.6 \mu \mathrm{m}$, whereas the $18 \%$ and $20 \%$ silicone stents measured $126.6 \pm 1.0$ and $131.2 \pm 1.2 \mu \mathrm{m}$, respectively; these results showed a positive correlation between coating thickness and material concentration. On the other hand, polyurethane stents at concentrations of 15,18 , and $20 \%$ resulted in mean coating thicknesses of $109.4 \pm 1.0,115.4 \pm 1.0,119.5 \pm$ $1.6 \mu \mathrm{m}$, respectively. These comparative measurements of various concentrations indicated that the silicone coating was thicker than the polyurethane coating.

Changes in the Surface of Stent Membranes. After immersing the covered stents in simulated gastric acid ( $\mathrm{pH} 1.2)$ for 18 weeks, changes in the surface of the stent membranes were examined using a SEM (Figures 1-3).

Comparison of stent membranes with varying silicone concentrations before immersion in simulated gastric acid (baseline; 0 week) revealed that the $20 \%$ silicone membrane showed the best surface uniformity. The membrane of $20 \%$ silicone shows regular surface and minimal change of degradation in acid environment, compared to $15 \%$ and $18 \%$ silicone. Sim-

Table 1. Coating Thickness of Covered Stent according to the Membrane Composition and Material Concentration

\begin{tabular}{ccc}
\hline Polymer & Concentration $(\%)$ & $\begin{array}{c}\text { Coating thickness } \\
(\mu \mathrm{m})\end{array}$ \\
\hline \multirow{2}{*}{ Silicone } & 15 & $121.9 \pm 1.6$ \\
& 18 & $126.6 \pm 1.0$ \\
& 20 & $131.2 \pm 1.2$ \\
\hline \multirow{2}{*}{ Polyurethane } & 15 & $109.4 \pm 1.0$ \\
& 18 & $115.4 \pm 1.0$ \\
& 20 & $119.5 \pm 1.6$
\end{tabular}

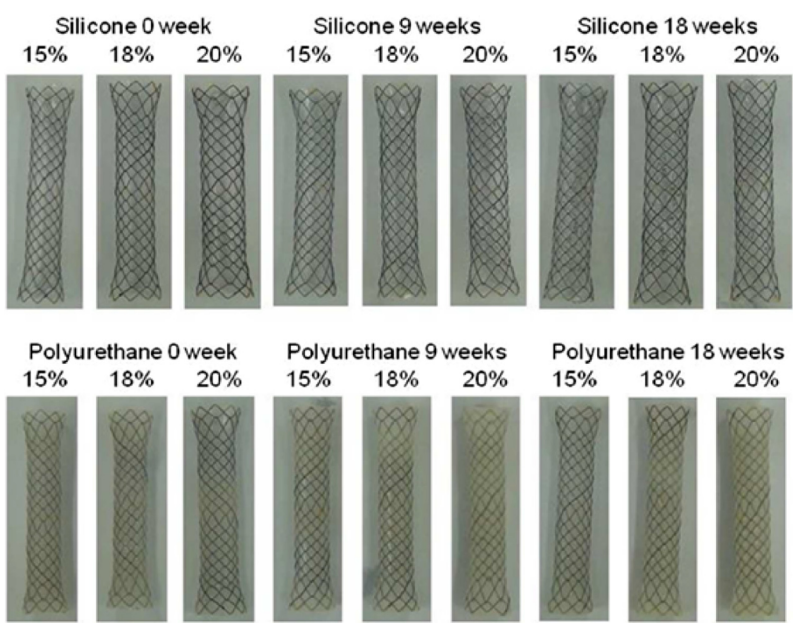

Figure 1. Temporal change of covered stent in simulated gastric acid.

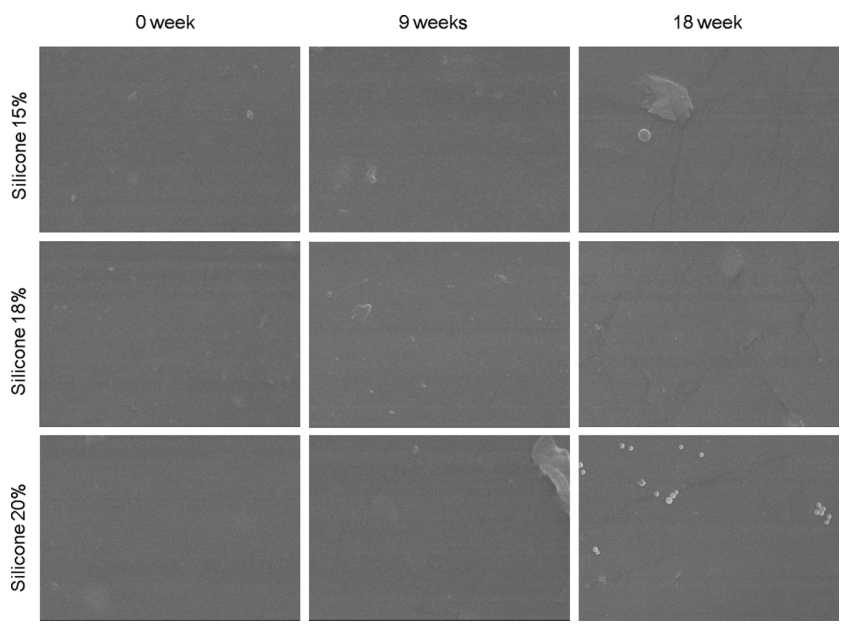

Figure 2. Scanning electron microscope (SEM) images of silicone membrane.

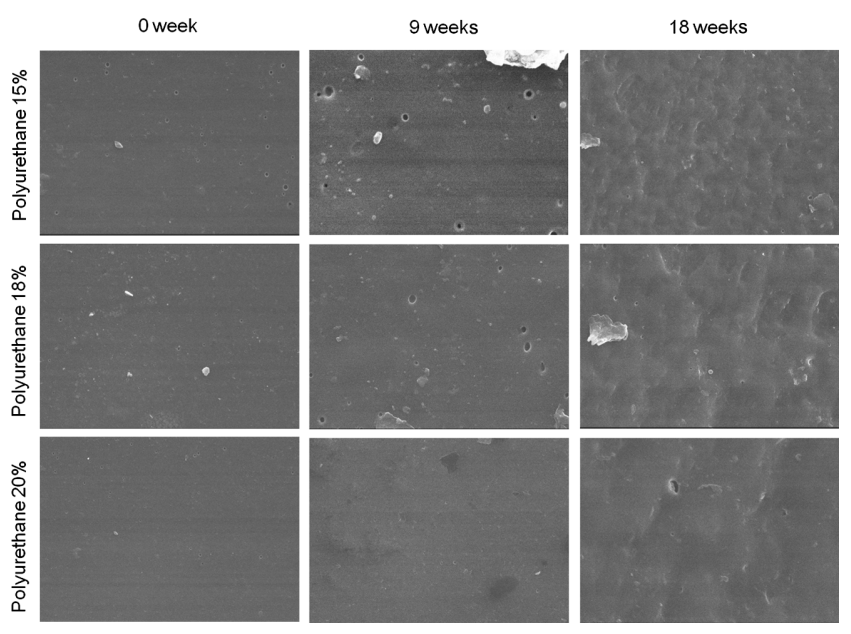

Figure 3. Scanning electron microscope (SEM) images of polyurethane membrane. 
ilarly, polyurethane membrane of high concentration is more homogeneous and resistant to acid environment than those of low concentration and the $20 \%$ polyurethane membrane also showed superior surface uniformity. However, comparison of silicone and polyurethane membranes at the same concentrations showed that silicone coating showed a higher level of uniformity. Surface roughness increased in all stent membranes as the immersion time in simulated gastric acid was prolonged. However, relatively smaller surface changes were observed in the silicone membranes than in the polyurethane membranes.

Radial Expansion Force and Recovery Force of Stent Membranes. Baseline measurements of the radial expansion force of 15,18 , and $20 \%$ silicone membranes were $392.7 \pm 2.5$, $398.0 \pm 3.0$, and $405.0 \pm 3.0$ gf, respectively, whereas those for 15,18 , and $20 \%$ polyurethane membranes were $369.7 \pm 2.5$, $375.0 \pm 3.0$, and $382.3 \pm 2.5$ gf, respectively. A positive correlation was observed between material concentration and radial expansion force (Figure 4). Silicone stents showed a higher expansion force than that by polyurethane stents at the same concentrations. As the immersion time in simulated gastric acid increased, the expansion force decreased accordingly at all concentrations. However, the rate of decrease in radial expansion force was $4.58 \%$ for the $15 \%$ silicone stent and $5.60 \%$ for $15 \%$ polyurethane, whereas it was $0.99 \%$ for the $20 \%$ silicone stent and $1.65 \%$ for the $20 \%$ polyurethane stent, indicating that the rate of decrease in radial expansion force was greater for lower material concentration (Figure 5).

At baseline, the recovery force of the $15 \%$ polyurethane stent was measured at $38.2 \pm 0.2 \mathrm{gf}$, which was the lowest value

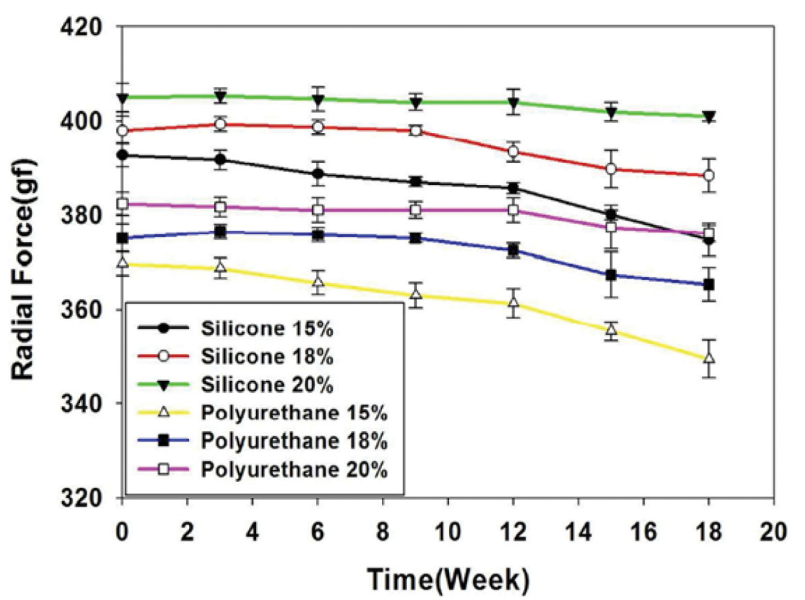

Figure 4. Radial expansion force of stent membranes according to material concentration. among all conditions (Figure 6). The recovery force of $15 \%$ silicone stent was $38.5 \pm 0.5$ gf, which was slightly higher than that of its polyurethane counterpart. The recovery forces of the $18 \%$ polyurethane stent and $18 \%$ silicone stent were $38.9 \pm 0.1$ and $39.1 \pm 0.1 \mathrm{gf}$, respectively whereas those for the $20 \%$ polyurethane stent and $20 \%$ silicone polyurethane were $40.0 \pm 0.4$ and $40.3 \pm 0.2 \mathrm{gf}$, respectively. These measurements indicated no significant differences in recovery force between the 2 stents at the same concentrations.

The recovery force measurements of the $15 \%$ polyurethane stents after immersion in simulated gastric acid for 6,12 , and 18 weeks were $38.2 \pm 0.4,37.9 \pm 0.1$, and $37.0 \pm 0.5 \mathrm{gf}$, respectively, indicating a slight but continuous decrease over time. A similar trend was also observed in stents of different con-

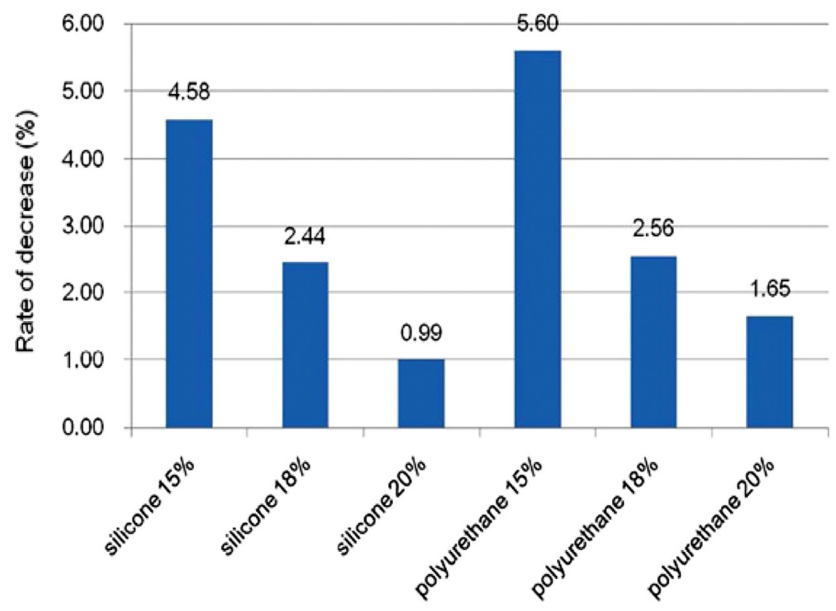

Figure 5. Ratio of decrease in the radial expansion force of stent from baseline ( 0 week) to 18 weeks according to the membrane composition and material concentration.

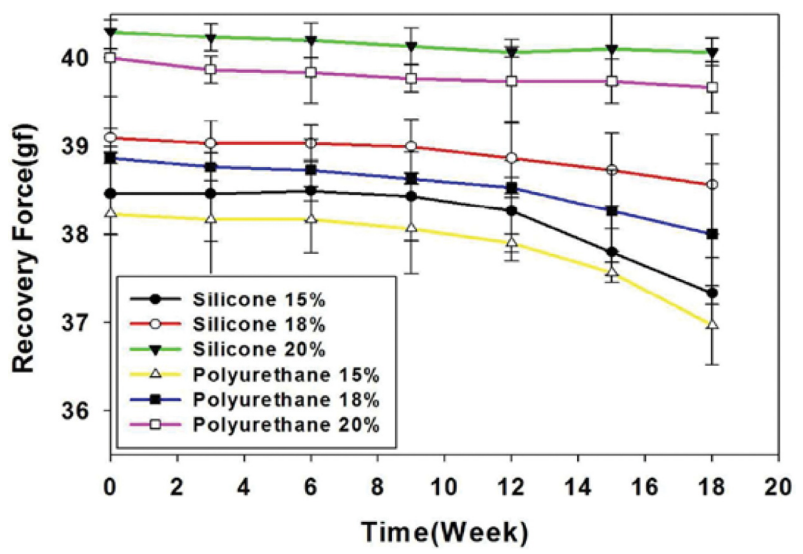

Figure 6. Recovery force of stent membranes according to material concentration. The recovery force of silicone membrane is not different from polyurethane membrane significantly. 


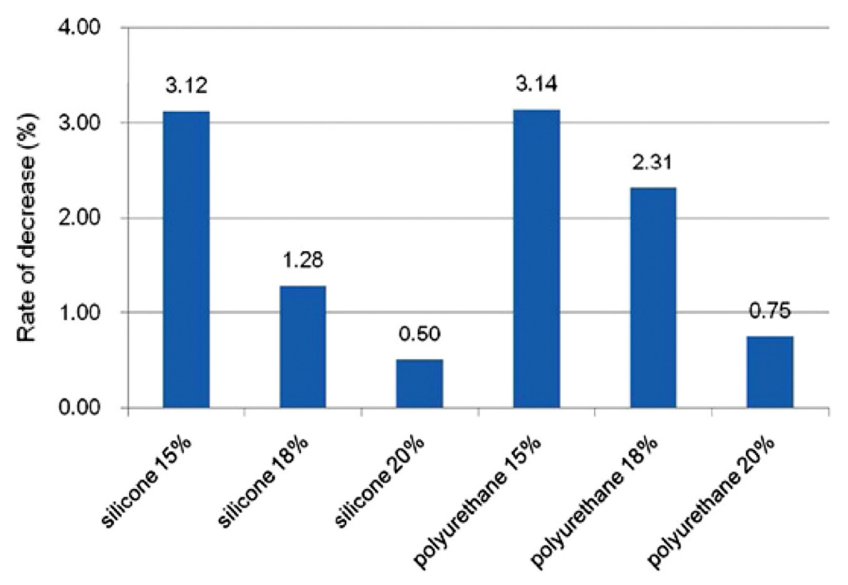

Figure 7. Rate of decrease in the recovery force of stent from baseline ( 0 week) to 18 weeks according to the membrane composition and material concentration.

centrations.

The decrease in the rate of recovery force over the 18-week of experiment was $3.12 \%$ in the $15 \%$ silicone stents and $3.14 \%$ in the $15 \%$ polyurethane stents, whereas in the $20 \%$ silicone stent, the rate was $0.50 \%$ and in $20 \%$ polyurethane stents, it was $0.75 \%$. These results indicate that the decrease in the rate of recovery increases as the concentration of the coating material decreases (Figure 7).

Membrane-covered GI stents were developed were developed to prevent stent occlusion due to tumor ingrowth, by coating metal alloy wires with a polymeric membrane., ${ }^{9,10}$ However, there are few comparative studies of the efficacy of coating membranes such as silicone, polyurethane, and e-PTFE according to its composition or material concentration. ${ }^{11,12}$ Therefore, the aim of the present study was to examine the physical changes that occur in membrane-covered stents when exposed to gastric acid for approximately 18 weeks.

Silicone and polyurethane are the most widely used coating materials for stents. Silicone is a synthetic rubber that has properties of high thermal and chemical stability. ${ }^{13}$ The properties of silicone, such as heat resistance, electrical insulation, hydrophobicity, non-volatility, and viscoelasticity, largely contribute to its biocompatibility and biodurability. Additionally, it has a very low surface tension, surface energy, and intermolecular interactions, thus rendering it chemically stable. Despite such stable surface characteristics, silicone tends to chemically degrade when exposed to a strong catalyst, resulting in its depolymerization. When silicone is affixed in the stomach for an extended period of time, its exposure to gastric acid often results in its chemical degradation. ${ }^{14}$ Moreover, although it is stable in an aqueous environment, degradation may still occur when in contact with fatty or non-polar substances, due to its lipophilic property. McHenry et al. reported incidences of in vivo degradation of silicone containing prosthetic heart valves and valve insufficiencies caused by the lipid components of blood. ${ }^{15}$

Polyurethane is a polymer consisting of urethane molecules as its skeleton. ${ }^{16}$ This synthetic resin offers a wide range of applications, including soft sponges, roller-skate wheels, shoe soles, faux leather, and skis. Its elasticity is far superior over all other synthetic rubber materials; it is highly resistant to abrasion and possesses excellent adhesion strength to blood and body tissues, thus it has been widely used as medical raw material for various medical tools such as artificial valves, blood vessels, and heart.

As elucidated above, both silicone and polyurethane are considered as the most popular biomaterials due to their excellent biocompatibility; however, these materials tend to undergo degradation when situated within a gastric acid environment. In addition, the comparative study of the coating composition or its concentration in the acid environment is not known yet. This study, thus, examined the gastric acid-induced degradation processes of both materials in terms of surface morphology and mechanical characteristics.

Changes in surface morphology of silicone- and polyurethane-covered stents immersed in simulated gastric acid $(\mathrm{pH}$ 1.2) for 18 weeks were examined using SEM. Our results showed that a high degree of degradation occurred among lowconcentration materials. In addition, polyurethane membranes showed a higher degradation rate than that by silicone membranes, thus, confirming that polyurethane membrane is more vulnerable in simulated gastric acid environment than silicone membrane.

Several studies have shown the degradation of polyurethane membrane. Jung et al. ${ }^{3}$ reported an $8 \%$ tumor ingrowth rate (3 out of 39 cases). Kim et al. ${ }^{7}$ reported that the degradation rate of e-PTFE membrane was $1 \%$ ( 1 out of 74 cases), whereas that of polyurethane membrane was $14 \%$ (13 out of 92 cases), thus, demonstrating the vulnerability of polyurethane membrane. Kim et al. ${ }^{14}$ also identified factors that influenced more membrane degradation, including stricture location (stomach or anastomosis $>$ esophagus), membrane material (polyurethane $>$ PTFE), and the length of time after stent insertion (36 days or more $>35$ days or less). In other study on the stability of the polyurethane membrane to the bile, pits and cracks on the membrane surface developed 2 weeks after its immersion in 
bile acids.

Changes in the mechanical properties of the stents were monitored in terms of radial expansion force and recovery force. ${ }^{17-20}$ Although shortening ratio and radiopacity are mechanical features associated with stent insertion process, radial expansion force and recovery force are important factors associated with the stent patency and dysfunction after its insertion. ${ }^{21}$

The extent of radial expansion force mainly depends on the material type and thickness of the metal alloy wire, number of wire bends, and method of weaving the wire. If the radial expansion force is weaker than the pressure of the tissues surrounding the stricture area, the stent fails to achieve its expected expansion, which may then lead to stent migration or occlusion. On the other hand, excessive force can compress the adjacent tissues, thus, causing chest pain, bleeding, perforation, or pressure necrosis. ${ }^{8}$ To prevent stent migration and maintain patency, the radial expansion force should be maintained at an appropriate level.

Recovery force, also known as axial force, is the force exerted by a bent stent to restore its original straight form; this force involves the nature of going back to the original state after stent insertion in a curved body lumen. It affects the conformability of the stent, allowing it to match the curves of upper GI tract including esophagus, stomach, duodenum, and bile duct; thus, the conformability of a stent increases as the recovery force decreases. An excessively strong recovery force often results in dysfunctional stents, including those observed as stent kinking, stent migration, or causing injury to the adjacent tract inner wall and production of bile sludge. ${ }^{21}$ The ideal stent, thus, possesses a strong radial expansion force and a weak recovery force.

The results of this study revealed that the radial expansion force of silicone and polyurethane measured at baseline (0 week) increased with higher concentration of the materials (sil-

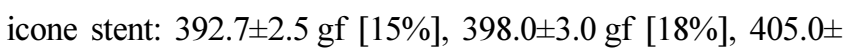
3.0 gf [20\%]; polyurethane stent: $369.7 \pm 2.5$ gf [15\%], 375.0 $\pm 3.0 \mathrm{gf}[18 \%], 382.3 \pm 2.5 \mathrm{gf}[20 \%])$. The comparison of radial expansion forces by using the same material concentrations revealed that silicone stents were higher by $6.0-6.2 \%$ than that of polyurethane stents.

Monitoring changes in both materials immersed in simulated gastric acid over time showed that the expansion force decreased in both silicone and polyurethane stents. Over a period of 18 weeks, silicone stents showed a less decrease in the rate of radial expansion force in $15 \%$ material concen- tration that in the polyurethane $(4.58 \%$ vs. $5.60 \%)$. Similar trends were observed with 18 and $20 \%$ material concentrations (2.44\% vs. $2.56 \%$ and $0.99 \%$ vs. $1.65 \%$, respectively). Our results showed that when the material concentration was high, the reduction in the rates of radial expansion force was less. The recovery force at baseline was $38.2 \pm 0.2 \mathrm{gf}$ in $15 \%$ polyurethane stent and $38.5 \pm 0.5 \mathrm{gf}$ in $15 \%$ silicone stent; the difference in recovery force between the two was $0.79 \%$. The differences in recovery force in the 18 and $20 \%$ concentrations were 0.50 and $0.75 \%$, respectively. The recovery force of the polyurethane membrane stent was slightly weaker, although not significant. During immersion in simulated gastric acid, the recovery force of each stent continuously decreased. During the 18-week experimental period, the decrease in the rates of recovery force were 3.12 and $3.14 \%$ in the $15 \%$ silicone and polyurethane stents, whereas the rates were 0.5 and $0.75 \%$ in the $20 \%$ silicone and polyurethane stents, respectively, showing that the decrease in the rates were slightly lower in the silicone stents than in the polyurethane stents. Thus, when the material concentration was high, the decrease in the rates of the recovery force was less. However, in the case of the measured recovery force presented the experimental results, the changes in the physical properties of material which is exposed to the acidic solution was minimal considering the deviation. Therefore, a statistically significant result did not come out.

The silicone membrane showed a better radial expansion force and similar recovery force. Both materials continuously lost their radial expansion force and recovery force while immersed in simulated gastric acid over time. This may be attributable to progressive membrane degradation, which impairs the mechanical properties of the stents. The decrease in the radial expansion force was more significant in the polyurethane membranes throughout the 18-week period; this may be attributable to the relative susceptibility of polyurethane membrane to the gastric acid.

The limitations of the present study in investigating the degradation and changes in the mechanical properties of covered stents in a gastric acid environment include the following. First, this in vitro experiment could not sufficiently reflect the in vivo changes that might occur on the stents. In addition to the degradations caused by the acidic gastric juice, the upper GI tract stent is exposed the degradation risk caused by bile and pancreatic digestive enzymes. In addition, the durability of the membrane may also be affected by mechanical damages caused by the peristaltic movement of the GI tract and the pressure exerted by the tissues surrounding the inserted stent. 
Second, the 18-week duration of the experiment was insufficient to determine subsequent changes to the stents. Third, the e-PTFE material, which is also widely used for membrane production along with silicone and polyurethane, was excluded from the scope of this study.

\section{Conclusions}

Our study showed a positive correlation between coating thickness and material concentration. In addition, the membrane surface of silicone-coated stents showed a higher level of uniformity compared to polyurethane-covered stents; surface uniformity also improved as the concentration level of the material was increased. Silicone showed a higher radial expansion force, although no significant differences in the recovery force between the two materials were observed. Immersion of stents in simulated gastric acid grew gradually resulted in a reduction in its mechanical properties; more significant changes were observed in polyurethane stents. The results of this study, thus, verify the high level of stability of high-concentration silicone membranes in simulated gastric acid, which may be verified forward in vivo experiments. It also needs more quantitative experiment for degradation of SEMS in future study.

Acknowledgement: The authors have no financial conflicts of interest.

\section{References}

1. H. J. Chun, E. S. Kim, J. J. Hyun, Y. D. Kwon, B. Keum, and C. D. Kim, J. Gastroenterol. Hepatol., 25, 234 (2010).

2. J. H. Zhou, Y. G. Jiang, R. W. Wang, Y. D. Lin, T. Q. Gong, Y. P. Zhao, Z. Ma, and Q. Y. Tan, J. Thorac. Cardiovasc. Surg., 130, 449 (2005).

3. G. S. Jung, H. Y. Song, T. S. Seo, S. J. Park, J. Y. Koo, J. D. Huh, and Y. D. Cho, J. Vasc. Interv. Radiol., 13, 275 (2002).

4. H. J. Park, Y. K. Cho, and W. T. Kim. J. Korea Radiol. Soc., 59, 321 (2008).
5. R. R. Saxon, R. E. Barton, R. M. Katon, P. C. Lakin, H. A. Timmermans, B. T. Uchida, F. S. Keller, and J. Rosch, J. Vasc. Interv. Radiol., 6, 237 (1995).

6. J. Schaer, R. M. Katon, K. Ivancev, B. Uchida, J. Rosch, and K. Binmoeller, Gastrointest. Endosc., 38, 7 (1992).

7. J. H. Kim, H. Y. Song, J. H. Shin, H. Y. Jung, S. B. Kim, and S. I. Park, J. Vasc. Interv. Radiol., 19, 220 (2008).

8. K. B. Lee, H. J. Chun, Y. B. Kim, Y. S. Kim, J. H. Park, T. Moon, D. Hong, and J. H. Hyun, Korean J. Gastrointest. Endosc., 23, 61 (2001).

9. H. Isayama, Y. Komatsu, T. Tsujino, H. Yoshida, M. Tada, Y. Shiratori, T. Kawabe, and M. Omata, Gastrointest. Endosc., 55, 366 (2002).

10. H. Saito, Y. Sakurai, A. Takamura, and K. Horio, Nihon Igaku Hoshasen Gakkai Zasshi, 54, 180 (1994).

11. B. W. Bang, S. Jeong, D. H. Lee, J. I. Lee, S. C. Lee, and S. G. Kang, Dig. Dis. Sci., 57, 1056 (2012).

12. D. H. Kim, S. G. Kang, J. R. Choi, J. N. Byun, Y. C. Kim, and Y. M. Ahn, Korean J. Radiol., 2, 75 (2001).

13. A. Mashak and A. Rahimi, Iran Polym. J., 18, 279 (2009).

14. A. Colas and J. Curtis, "Silicone biomaterials: history and chemistry", in Biomaterials science: an introduction to materials in medicine, B. D. Ratner, A. S. Hoffman, F. J. Schoen, and J. E. Lemons, Editors, Elsevier, Amsterdam, p 80 (2004).

15. M. M. McHenry, E. A. Smeloff, W. Y. Fong, G. E. Miller, and P. M. Ryan, J. Thorac. Cardiovasc. Surg., 59, 413 (1970).

16. K. Yasumori, N. Mahmoudi, K. C. Wright, S. Wallace, and C. Gianturco, J. Vasc. Interv. Radiol., 4, 773 (1993).

17. S. H. Duda, J. Wiskirchen, G. Tepe, M. Bitzer, T. W. Kaulich, D. Stoeckel, and C. D. Claussen, J. Vasc. Interv. Radiol., 11, 645 (2000).

18. J. F. Dyet, W. G. Watts, D. F. Ettles, and A. A. Nicholson, Cardiovasc. Intervent. Radiol., 23, 47 (2000).

19. S. Miura, T. Yoshioka, K. Furuichi, T. Tanaka, K. Kichikawa, and H. Ohishi, Nihon Igaku Hoshasen Gakkai Zasshi, 63, 201 (2003).

20. D. Stoeckel, A. Pelton, and T. Duerig, Eur. Radiol., 14, 292 (2004).

21. H. Isayama, Y. Nakai, Y. Toyokawa, O. Togawa, C. Gon, Y. Ito, Y. Yashima, H. Yagioka, H. Kogure, T. Sasaki, T. Arizumi, S. Matsubara, N. Yamamoto, N. Sasahira, K. Hirano, T. Tsujino, N. Toda, M. Tada, T. Kawabe, and M. Omata, Gastrointest. Endosc., 70, 37 (2009). 